\title{
Bringing the JBP and its readers closer together
}

\author{
$0 \mathrm{JBP}$ mais próximo do leitor
}

Rogério Souza ${ }^{1}$

There is no denying the role that a scientific journal plays in the dissemination of existing or newly acquired knowledge in a given area of expertise. In addition, an essential part of the mission of a scientific journal is to promote a discussion of controversial issues in order to give rise to new views and ideas that will encourage further research on a given topic. However, publications with a narrower focus tend to have less visibility than do those with a broader scope. Nevertheless, scientific journals, particularly those that were originally regional journals, have another, less obvious, role.

The JBP was created as and continues to be the official organ of the Brazilian Thoracic Association (BTA). ${ }^{(1)}$ The initial mission of the JBP was to disseminate knowledge in the field of pulmonology among the members of the BTA. However, the JBP, like the BTA itself, has grown and matured; in addition to disseminating knowledge, the JBP now reflects the growth and internationalization of respiratory research in Brazil and the world. ${ }^{(2)}$ Nevertheless, the process of internationalization, which is common to many journals that are expanding their reach, ${ }^{(3)}$ does not exempt the JBP from its fundamental role of disseminating and consolidating knowledge pertaining to the characteristics of the region from which it originates. This includes the publication of national guidelines on various diseases or clinical conditions, ${ }^{(4)}$ the dissemination of specific epidemiological data, the dissemination of predicted values for healthy individuals, ${ }^{(5,6)}$ the validation of Portuguese-language versions of instruments, ${ }^{(7)}$ and the provision of support to emerging fields of research and research groups in Brazil..$^{(8-10)}$ Far from being trivial, this is a role that merits ongoing attention.

Scientific metrics, which do not necessarily reflect the full range of activities of a researcher, an institution, or even a journal, are currently overvalued. ${ }^{(11)}$ The quest for growth and increased exposure sometimes results in distortions that merit further reflection. Although objective quality analysis is desirable, indicators should not be analyzed without taking into consideration the methodology whereby they were created and their limitations. From an editorial standpoint, the impact factor, created by Eugene Garfield in 1955 as a tool for determining the representativeness of a journal, is currently the most widely used indicator. 1ts widespread acceptance was certainly a positive occurrence. However, the impact factor has become an absolute indicator of the quality of a journal. This is a conceptual error. The merits of a journal dedicated to a very specific area of knowledge can hardly be judged on the basis of the impact factor alone. This leads us back to the initial question: What is the true role of the JBP? In view of the aforementioned considerations, it is our desire to expand internationally without losing sight of our mission of meeting local needs. Regarding the impact factor of the JBP, there is undoubtedly room for improvement. Our 2014 impact factor, which will be published this year, is expected to decrease; however, it will increase again next year, further increasing our international exposure. Nevertheless, this should not be the focus of editorial work-albeit a direct consequence thereof-until a balance is struck between internationalization and local relevance.

In order to meet the aforementioned challenge, the print version of the JBP will now be published entirely in Portuguese, with the exception of articles submitted in Spanish. We therefore expect that all BTA members will read the print version of the JBP when it is published, once every two months. The Portuguese-language version of the JBP will also be available online (at www. jornaldepneumologia.com.br), together with a version entirely in English; therefore, readers from abroad who gain access to our articles via PubMed will continue to have direct access to English-language versions of all articles. In addition, the JBP now has two new sections: lmaging in Pulmonary Medicine and Continuing

1. Tenured Professor, Instituto do Coração - InCor, Heart Institute - University of São Paulo School of Medicine Hospital das Clínicas, São Paulo; and Editor-in-Chief of the JBP, Brasilia, Brazil. 
Education. The lmaging in Pulmonary Medicine section(12) is an idea that has been tried out by several former JBP editors and that is being put into practice again. The section will not be restricted to radiological results but will be used in order to showcase any images that might be of interest to readers, including those depicting endoscopic findings, radiological findings, or even unusual or well-documented preliminary clinical findings. The Continuing Education section is not exactly a section, but rather a heading under which certain series will be published in the JBP. The first such series, which begins in the current issue of the JBP, is designated "Continuing Education: Imaging" and is overseen by associate editors Edson Marchiori and Bruno Hochhegger. ${ }^{(13)}$ In that series, practical aspects of routine radiological findings in the field of respiratory medicine will be discussed. Other Continuing Education series are under development and will address the many facets of the field of respiratory medicine.

The objective of the aforementioned changes is to bring the JBP and its readers-researchers, clinicians, surgeons, and even those who simply wish to stay up-to-date with the latest trends in the field of respiratory medicine-closer together. We hope that all JBP readers can learn something from each issue; that is our ultimate goal!

\section{References}

1. Souza R. 2015--another step along the road in a 40-year journey... J Bras Pneumol. 2015;41(1):1-2. http://dx.doi. org/10.1590/S1806-37132015000100001

2. Carvalho CR, Baldi BG, Jardim CV, Caruso P, Souza R. New steps for the international consolidation of the Brazilian Journal of Pulmonology. J Bras Pneumol. 2014;40(4):325-6. http://dx.doi.org/10.1590/ S1806-37132014000400001
3. Souza R, Carvalho CR. Brazilian Journal of Pulmonology and Portuguese Journal of Pulmonology: strengthening ties in respiratory science. Rev Port Pneumol. 2014;20(6):285-6. http://dx.doi.org/10.1016/j.rppneu.2014.11.001

4. Brazilian recommendations of mechanical ventilation 2013. Part 2. J Bras Pneumol. 2014;40(5):458-86. http:// dx.doi.org/10.1590/S1806-37132014000500003

5. Moreira GL, Manzano BM, Gazzotti MR, Nascimento OA, Perez-Padilla R, Menezes AM, et al. PLATINO, a nine-year follow-up study of COPD in the city of São Paulo, Brazil: the problem of underdiagnosis. J Bras Pneumol. 2014;40(1):30-7. http://dx.doi.org/10.1590/ S1806-37132014000100005

6. Dourado VZ, Guerra RL, Tanni SE, Antunes LC, Godoy 1. Reference values for the incremental shuttle walk test in healthy subjects: from the walk distance to physiological responses. J Bras Pneumol. 2013;39(2):190-7. http:// dx.doi.org/10.1590/S1806-37132013000200010

7. Valderramas S, Camelier AA, Silva SA, Mallmann R, de Paulo HK, Rosa FW. Reliability of the Brazilian Portuguese version of the fatigue severity scale and its correlation with pulmonary function, dyspnea, and functional capacity in patients with COPD. J Bras Pneumol. 2013;39(4):427-33. http://dx.doi.org/10.1590/S1806-37132013000400005

8. Corrêa Rde A, Silva LC, Rezende CJ, Bernardes RC, Prata TA, Silva HL. Pulmonary hypertension and pulmonary artery dissection. J Bras Pneumol. 2013;39(2):238-41. http://dx.doi.org/10.1590/S1806-37132013000200016

9. Gavilanes F, Alves JL Jr, Fernandes C, Prada LF, Jardim $\mathrm{CV}$, Morinaga LT, et al. Left ventricular dysfunction in patients with suspected pulmonary arterial hypertension. J Bras Pneumol. 2014;40(6):609-16. http://dx.doi. org/10.1590/S1806-37132014000600004

10. Polonio IB, Acencio MM, Pazetti R, Almeida FM, Silva BS, Pereira KA, et al. Lodenafil treatment in the monocrotaline model of pulmonary hypertension in rats. J Bras Pneumol. 2014;40(4):421-4. http://dx.doi. org/10.1590/S1806-37132014000400010

11. Casadevall A, Fang FC. Causes for the persistence of impact factor mania. MBio. 2014;5(2):e00064-14. Erratum in: MBio. 2014;5(3):e01342-14.

12. Lima E, Nagy AL, Athanazio RA. Intracavitary pulmonary aspergilloma: endoscopic aspects. J Bras Pneumol. 2015;41(3):285.

13. Marchiori E, Zanetti G, Hochhegger B. Small interstitial nodules. J Bras Pneumol. 2015;41(3):250. 